Original Article

\title{
Reduced genetic diversity and the success of the invasive peacock bass (Cichliformes: Cichlidae)
}

\author{
Diversidade genética reduzida e o sucesso da espécie invasora tucunaré (Cichliformes: \\ Cichlidae)
}

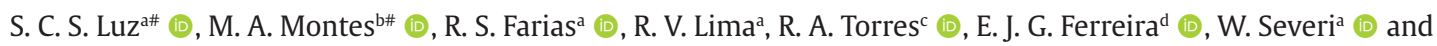
M. R. M. Coimbra ${ }^{a^{*}}$ (D)

aUniversidade Federal Rural de Pernambuco - UFRPE, Departamento de Pesca e Aquicultura, Recife, PE, Brasil

bUniversidade Federal Rural de Pernambuco - UFRPE, Departamento de Biologia, Recife, PE, Brasil

cUniversidade Federal de Pernambuco - UFPE, Departamento de Zoologia, Recife, PE, Brasil

dInstituto Nacional de Pesquisas da Amazônia - INPA, Coordenação de Biodiversidade, Manaus, AM, Brasil

\begin{abstract}
Several species of Cichla successfully colonized lakes and reservoirs of Brazil, since the 1960's, causing serious damage to local wildlife. In this study, 135 peacock bass were collected in a reservoir complex in order to identify if they represented a single dominant species or multiple ones, as several Cichla species have been reported in the basin. Specimens were identified by color pattern, morphometric and meristic data, and using mitochondrial markers COI, 16S rDNA and Control Region (CR). Overlapping morphological data and similar coloration patterns prevented their identification using the taxonomic keys to species identification available in the literature. However, Bayesian and maximum likelihood from sequencing data demonstrated the occurrence of a single species, Cichla kelberi. A single haplotype was observed for the $16 \mathrm{~S}$ and $\mathrm{CR}$, while three were detected for COI, with a dominant haplotype present in $98.5 \%$ of the samples. The extreme low diversity of the transplanted C. kelberi evidenced a limited number of founding maternal lineages. The success of this colonization seems to rely mainly on abiotic factors, such as increased water transparency of lentic environments that favor visual predators that along with the absence of predators, have made $C$. kelberi a successful invader of these reservoirs.
\end{abstract}

Keywords: cichlid, low genetic diversity, bottleneck, transplanted species, top predator.

\begin{abstract}
Resumo
Muitas espécies de Cichla colonizaram com sucesso lagos e reservatórios do Brasil desde os anos 1960, causando graves prejuízos à vida selvagem nesses locais. Neste estudo, 135 tucunarés foram coletados em um complexo de reservatórios a fim de identificar se representavam uma espécie dominante ou múltiplas espécies, uma vez que diversas espécies de Cichla foram registradas na bacia. Os espécimes foram identificados com base na coloração, dados morfométricos e merísticos, e por marcadores mitocondriais COI, 16S rDNA e Região Controle (RC). A sobreposição dos dados morfométricos e o padrão similar de coloração impediram a identificação utilizando as chaves de identificação disponíveis na literatura. Entretanto, as análises bayesiana e de máxima verossimilhança de dados moleculares demonstraram a ocorrência de uma única espécie, Cichla kelberi. Um único haplótipo foi observado para o $16 \mathrm{~S}$ e RC, enquanto três foram detectados para o $\mathrm{COI}$, com um haplótipo dominante presente em $98,5 \%$ das amostras. A baixa diversidade nos exemplares introduzidos de $C$. kelberi evidenciou um número limitado de linhagens maternas fundadoras. O sucesso da invasão parece depender de fatores abióticos, como a maior transparência da água de ambientes lênticos que favorece predadores visuais que, atrelado à ausência de predadores, fez do C. kelberi um invasor bem-sucedido nesses reservatórios.
\end{abstract}

Palavras-chave: ciclídeo, baixa diversidade genética, efeito gargalo, espécies introduzidas, predador de topo.

\section{Introduction}

Peacock basses (genus Cichla; Cichliformes: Cichlidae) are native to the Amazon, Tocantins and Orinoco basins, as well as Atlantic-slope rivers of the Guianas and Suriname (Kullander and Ferreira, 2006). They are non-migratory carnivorous fish, with parental care, as they build nests and protect their offspring (Gomiero et al., 2009). They are among the most frequently introduced species in Brazil for sport fishing in reservoirs, lakes and rivers (Gomiero and

*e-mail: maria.rmcoimbra2@ufrpe.br

\#Luz and Montes should be considered joint first author.

Received: February 11, 2021 - Accepted: September 10, 2021 
Braga, 2003; Ferrareze and Nogueira, 2015; Marques et al., 2016), as also in North America, Africa and Asia (Golani et al., 2019; Sastraprawira et al., 2020), and represent a potential threat to the native fish fauna.

The introduction of species causes problems related to the dissemination of diseases and/or parasites and predator-prey interactions. For example, invasions of Cichla spp. in rivers and lakes of Panama have drastically reduced fish assemblages (Zaret and Paine, 1973), from which they have not yet recovered (even after 45 years) (Sharpe et al., 2017), and has been associated to the extinction of native species in the Atlantic Forest of Brazil (Pelicice and Agostinho, 2009; Fragoso-Moura et al., 2016). In invasions, aspects such as history of successful colonization, high physiological tolerance, an ability to deal with anthropogenic impact on a habitat, similar conditions between source and recipient environment, and large propagule size (>100 individuals) have been described as key factors used to predict successful invasions (Moyle and Marchetti, 2006).

In the case of peacock bass invasions in reservoirs, environmental factors seem to favor this diurnal visual predator. Espínola et al. (2010) compared 63 Brazilian reservoirs with records of presence/absence of Cichla, and corroborated that the deepest, most transparent and warmest reservoirs were the most colonized ones. Later, Franco et al. (2018) examined other 12 Brazilian reservoirs and concluded that the abundance of Cichla was associated with warm temperatures and low turbidity, what is due to increased water residence time.

One of the primordial aspects when assessing peacock bass colonization is the taxonomic identity of the invaders, i.e., if there is one dominant species or a group of them. The genus Cichla shows an extensive phenotypic variation, especially related to the color pattern, which can be very confusing for species identification (Reiss et al., 2012; Quadros et al., 2020). The misidentification of several Cichla species introduced in different regions of Brazil was previously reported by Kullander and Ferreira (2006), such as for C. kelberi (Kullander \& Ferreira, 2006), which was erroneously identified as C. monoculus Spix \& Agassiz, 1831 and C. piquiti (Kullander \& Ferreira, 2006), due to the overlapping morphometric characters and similar coloration patterns. Molecular data could be a useful complement for more conclusive identification in complex genus, such as Cichla, due to conflicting morphometric and meristic characteristics.

Four peacock bass species (C. kelberi, C. piquiti, C. temensis (Humboldt, 1821), and C. monoculus) have reportedly been introduced into lakes, reservoirs, tributaries, and the main channel of the São Francisco River Basin (Pompeu and Godinho, 2003; Sato and Sampaio, 2005; Carvalho et al., 2009). However, due to the different morphotypes found in this river system, it is unclear whether they represent multiple species or a single one.

In this context, molecular data could be a useful complement for more conclusive identification in complex genus, such as Cichla, due to conflicting morphometric and meristic characteristics. The use of molecular tools as a method of taxonomic identification of closely related species has been previously reported (Carvalho et al., 2009;
Hashimoto et al., 2016). Mitochondrial markers such as cytochrome c oxidase subunit I(COI), 16S ribosomal DNA, and control region (CR), are widely used as molecular tools to aid in the identification of freshwater fish species (Cheng et al., 2012; Pereira et al., 2013; Quraishia et al., 2015; Saad, 2019).

The purpose of this study was to determine if one or more species of Cichla have been introduced into reservoirs of the basin using morphometric and genetic data.

\section{Material and Methods}

\subsection{Ethics statement}

All biological material used in this research came from artisanal fishery and data were collected at landing ports. No live specimen was kept in captivity or manipulated. Therefore, no ethical approval was necessary.

\subsection{Fish sampling and identification}

The samples were obtained after the fish were caught by artisanal fishermen, at landing sites in three reservoirs, Moxotó, Delmiro Gouveia and PA IV, located in the submiddle stretch of the São Francisco River (Figure 1).

Species identification was based on coloration, meristics, and morphological characteristics including presence/absence or placement of bars and spots on the body, lateral line scale counts and background side coloration, according to Kullander and Ferreira (2006). The taxonomical and morphometric analysis was performed on 113 specimens ( 77 females and 36 males), selected according to their morphological integrity such as undamaged fins and complete scale cover. Nine body measurements were taken using a digital caliper $(0.1 \mathrm{~mm})$, and 11 meristic characters were counted (Table 1) for taxonomical identification, following Kullander and Ferreira (2006). Body depth, caudal peduncle height, head depth, eye diameter and interorbital distance (expressed as proportions of standard length (SL)), along with meristic data and color were compared with those presented by Kullander and Ferreira (2006) for the four species of Cichla reported for the São Francisco basin. These authors described the living coloration on the side of $C$. kelberi, C. piquiti, C. monoculus and C. temensis, collected in naturally occurring basins, as “pale grey”, "greyish”, “dull olivaceous”, "yellowish" and "golden".

\subsection{Molecular analysis}

Based on extensive molecular data, Willis et al. (2012) considered only eight species: $C$. orinocensis, C. intermedia, C. ocellaris, C. temensis, C. melaniae, C. mirianae, C. piquiti, and C. pinima in the genus Cichla, instead of the 15 described by Kullander and Ferreira (2006). The C. monoculus, C. kelberi, C. nigromaculata and C. pleiozona were classified as subspecies of $C$. ocellaris sensu lato. In this study, $C$. kelberi and $C$. monoculus were considered as valid species, as most of the sequences of Cichla deposited in the GenBank followed Kullander and Ferreira (2006) classification. 


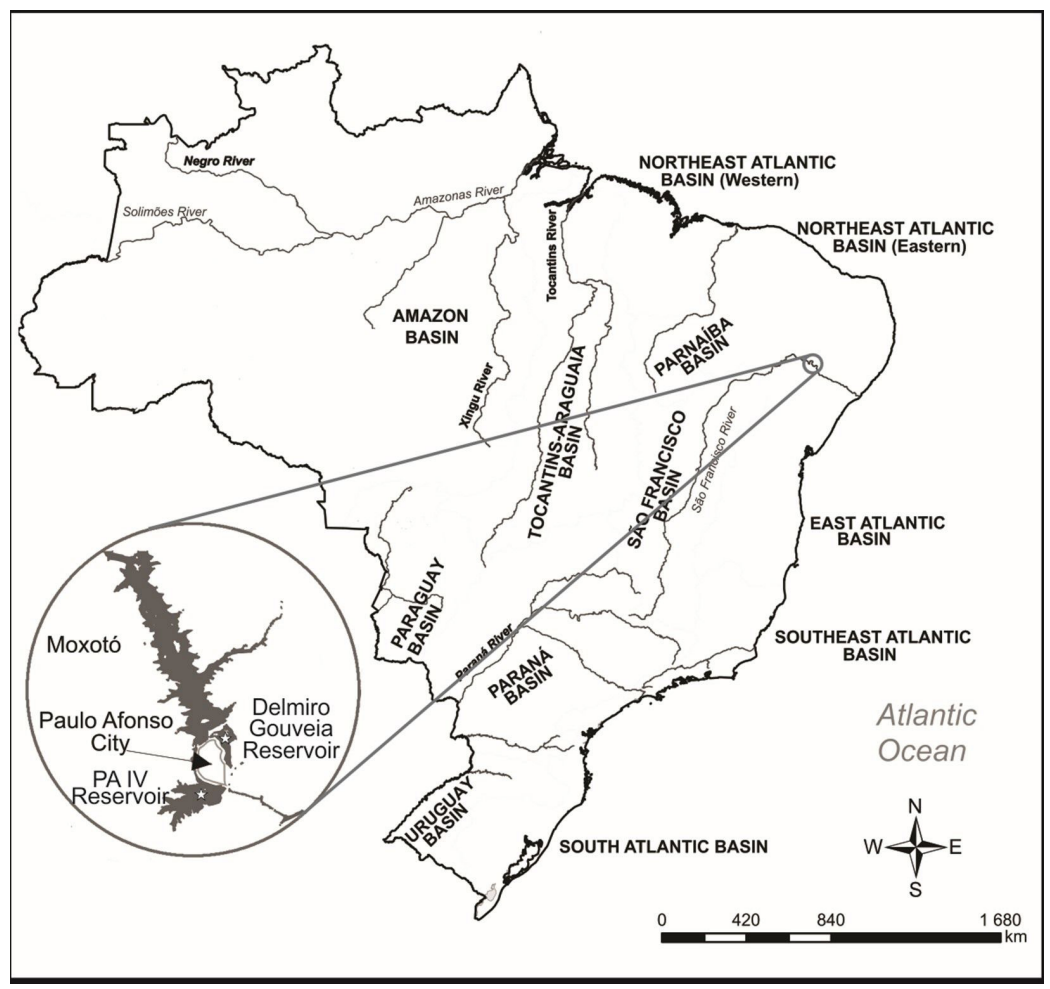

Figure 1. Brazilian hydrographic basins and sampling area in detail.

Table 1. Description of morphometric measurements and meristic data used.

\begin{tabular}{clll}
\hline & \multicolumn{1}{c}{ Meristic data } & & Longitudinal morphometric data \\
\hline $1^{\text {st }} \mathrm{DS}$ & $1^{\text {st }}$ dorsal fin spine number & $\mathrm{SL}$ & Standard length \\
$2^{\text {nd }} \mathrm{DS}$ & $2^{\text {nd }}$ dorsal fin spine number & $\mathrm{BD}$ & Body depth \\
$2^{\text {nd }} \mathrm{DR}$ & $2^{\text {nd }}$ dorsal fin ray number & $\mathrm{CPH}$ & Caudal peduncle height \\
CFR & Caudal fin ray number & HD & Head depth \\
AFR & Anal fin ray number & ED & Eye diameter \\
VFR & Ventral fin ray number & ID & Interorbital distance \\
PFRS & Pectoral fin ray and spine number & PDD & Predorsal distance \\
CPS & Caudal peduncle scale number & PVD & Preventral distance \\
ALL & Anterior lateral line scale number & PAD & Preanal distance \\
PLL & Posterior lateral line scale number & & \\
MLL & Median lateral line scale number & & \\
\hline
\end{tabular}

For molecular analysis, muscle samples from 135 specimens were collected from the caudal peduncle of each specimen and preserved in 95\% ethanol for subsequent extraction of genetic material. Additionally, four muscle samples (from naturally occurring basins) of $C$. piquiti (CP), identified as C. piquiti 01, C. piquiti 02, C. piquiti 03 , and $C$. piquiti 05 , and two muscle samples of C. kelberi, identified as C. kelberi 06 and C. kelberi 07, were collected from Tocantins River (TO) by Prof. Alberto Akama from the Museum Emílio Goeldi, Belém, Brazil.
Furthermore, two muscle samples of $C$. monoculus from Xingu River, C. monoculus 02 and C. monoculus 03 (Xingu Project), and two muscle samples of $C$. temensis (C. temensis 01 and $C$. temensis 02) from the Negro River (SUDAM Proc. nº CUP 59004/00473/2013-42) were all sequenced.

Total DNA was extracted using the modified phenolchloroform-isoamyl alcohol method (Sambrook et al., 1989). Three mitochondrial markers were amplified: Cytochrome c Oxidase subunit I (COI), 16S ribosomal DNA (16S), and Control Region (CR). Polymerase chain 
reaction (PCR) amplification of COI was performed with the primers BarcFish11 and BarcFish2, as described by Ward et al. (2005). Part of the $16 S$ and CR were amplified with the primers 16S-L1987 and 16S-H2909 as described by Palumbi et al. (1991), and L (Cronin et al., 1993), and H16498 (Meyer et al., 1990), respectively. Amplicons of $650 \mathrm{bp}$ (COI), $500 \mathrm{bp}$ (16S) and $460 \mathrm{bp}$ (CR) were purified with the enzymes ExoI/SAP and sequenced using a Genetic Analyzer (3500 Applied Biosystems, CA, USA).

\subsection{Data analysis}

The morphometric data were linearized in order to achieve a normal variance distribution, and transformed to eliminate allometric effects (Rohlf, 1990), using the equation $\mathrm{Y}^{*}{ }_{i}=\mathrm{Y}_{\mathrm{i}}\left(\mathrm{X}_{0} / \mathrm{X}_{\mathrm{i}}\right)^{\beta}$, which corrected size effects; where $\mathrm{Y}^{*}{ }_{i}=$ standardized morphometric measurement for each individual $\mathrm{i} ; \mathrm{Y}_{\mathrm{i}}=\mathrm{i}$-th morphometric measurement $\mathrm{Y} ; \mathrm{X}_{0}=$ average standard length (SL) of all individuals; $\mathrm{X}_{\mathrm{i}}=$ individual standard length $\mathrm{i}$; and $\beta=$ allometric coefficient from the linearized equation $\log Y i=\log \alpha+\beta \log X i$, using the entire sample.

All morphometric data were analyzed for normality and homoscedasticity. Since they did not meet the parametric requirements, the non-parametric Kruskal-Wallis test was conducted in order to evaluate differences among types and the other four Cichla species reported for this river system. All analyses were made using Statistica 6.0.

The DNA sequences were edited and aligned in the MEGA 7 program (Kumar et al., 2016), using ClustalW (Thompson et al., 1994). After trimming the poorquality regions, final alignments of 628 bp (COI), 408 bp (16S) and $358 \mathrm{bp}$ (CR) were obtained. The nucleotide sequences generated in this study were deposited in GenBank under the accession numbers MW248167MW248311 (COI), MW255385-MW255471 (16S), and MW251997-MW252032 (CR). GenBank sequences, whose specimens were taken from the naturally occurring basins of each species, were selected for subsequent comparisons. For 16S (C. kelberi FJ904290- Tocantins River; C. monoculus FJ904288- Solimões River and AF049017- Negro River; C. piquiti FJ904286- Tocantins River and C. temensis AF049019- Negro River; and for CR (C. kelberi JQ926871-JQ926872, FJ890808, FJ890812, FJ890813, GU295705-GU295707; C. monoculus GU295709GU295732 and DQ841872-DQ841899; C. piquiti JQ926783JQ926792 and C. temensis GU295739-GU295740 and DQ841909-DQ841929), all from different locations from the Amazonas, Orinoco, Essequibo, Maroni and Tocantins Rivers. In the phylogenetic trees, GenBank sequences were named by a combination of the species names ( $C$. monoculus, C. kelberi, $C$. temensis and $C$. piquiti), followed by the last three digits of their accession numbers.

Phylogenetic analyses for each marker were carried out with Maximum Likelihood (ML) and Bayesian Inference (BI). The best-fit model (COI $=\mathrm{HKY}+\mathrm{I}, 16 \mathrm{~S}=\mathrm{TIM} 2+\mathrm{I}$ and $\mathrm{CR}=\mathrm{HKY}+\mathrm{I})$ of nucleotide substitution was identified using jModelTest (Posada, 2008). The selected model was implemented into PhyML 3.0 (Guindon and Gascuel, 2003) to perform ML reconstruction using the approximate likelihood ratio test to evaluate node support.
Additionally, a probabilistic topology was obtained through Bayesian inference (BI). The BI analysis was conducted in MrBayes v.3.0b4 (Ronquist and Huelsenbeck, 2003) using 2,000,000 generations, with sampling every 100 generations, and a burn-in of $25 \%$. The default values of the program were used for the other variables. Support for the branches of the BI phylogenies was estimated with posterior probability (Huelsenbeck and Ronquist, 2001). Geophagus brasiliensis (Quoy \& Gaimard, 1824) (KU531434) was used as an outgroup for the three markers, considering recent phylogenetic evidence (López-Fernández et al., 2010).

The distance model Kimura 2-parameter (K2P) was used to estimate the overall mean genetic distance for all the COI samples, as implemented in MEGA 7 (Kimura, 1980; Kumar et al., 2016). Estimation of haplotypes number, frequencies of haplotypes, nucleotide and haplotype diversity, were performed using DNAsp v.5.10.00 software (Librado and Rozas, 2009). The haplotype network was determined using the Network 4.5.6 program and calculated using the median-joining algorithm (Bandelt et al., 1999).

\section{Results}

The morphometric and meristics data overlapped between the four reported species for the basin and the sampled individuals (Table 2 ), as well as the presence of a conflicting pigmentation pattern in the latter made their taxonomic identification unclear. Two distinct patterns of color and pigmentation were identified in the sampled individuals, what might suggest the presence of more than one species. Therefore, they were preliminarily classified into "gray-greenish" and "yellowish" types, considering the predominant $(>50 \%$ ) background side color (Figure 2 ).

Out of the 113 individuals included in the morphometric analysis, 46 ( $\mathrm{SL}=170-293 \mathrm{~mm}$ ) belonged to the "graygreenish" type, and 67 (SL=200-313 mm) to the "yellowish" type (Figure 2 ). The five body proportions were analyzed for differences between the two color types, and compared with the data for Cichla monoculus, C. kelberi, C. piquiti and C. temensis (Table 2). No significant differences were found for any of the body proportions analyzed between types alone, nor between types and the four Cichla species. Also, the counts of meristic data overlapped between the four Cichla species (Table 2).

Peacock bass specimens exhibited two color types and considerable morphometric variation, including overlapping morphological characters, which prevented their identification using the taxonomic keys available in the relevant literature. So, from this point on, all samples were identified by molecular analysis.

In the molecular analysis of COI, among the 135 individuals, three haplotypes were found containing two polymorphic sites and two mutations. The $\mathrm{C}+\mathrm{G}$ index was $46 \%$, the haplotype (hd) and nucleotide ( $\pi$ ) diversities were 0.03 and 0.00005 , respectively. The overall mean K2P distance for COI was 0.0000466 , suggesting that samples belong to the same species. For the $16 \mathrm{~S}$ and CR, the $\mathrm{G}+\mathrm{C}$ index was $46.7 \%$ and $30 \%$, respectively, and a single haplotype was detected in each marker. 
Table 2. Maximum, minimum and mean standard length (SL), body measurements' proportions in relation to SL, and meristic data of the "yellowish" and "gray-greenish" types, Cichla monoculus, C. kelberi, C. piquiti and C. temensis. Data for Cichla spp. as reported by Kullander and Ferreira (2006).

\begin{tabular}{|c|c|c|c|c|c|c|c|c|}
\hline \multirow{2}{*}{\multicolumn{2}{|c|}{$\begin{array}{l}\text { Morphometric } \\
\text { data }\end{array}$}} & \multicolumn{2}{|c|}{ Types } & \multicolumn{4}{|c|}{ Cichla spp. } & \multirow{3}{*}{ KW-H/p } \\
\hline & & \multirow{2}{*}{$\begin{array}{c}\text { “Yellowish" } \\
67(17 / 50)\end{array}$} & \multirow{2}{*}{$\begin{array}{c}\begin{array}{c}\text { “Gray- } \\
\text { greenish" }\end{array} \\
46(19 / 27)\end{array}$} & \multirow{2}{*}{$\begin{array}{c}\begin{array}{c}C . \\
\text { monoculus }\end{array} \\
35\end{array}$} & \multirow{2}{*}{$\begin{array}{c}\text { C. kelberi } \\
10\end{array}$} & \multirow{2}{*}{$\frac{\text { C. temensis }}{31}$} & \multirow{2}{*}{$\frac{\text { C. piquiti }}{20}$} & \\
\hline $\mathbf{N}(\mathrm{mal}$ & male) & & & & & & & \\
\hline \multirow[t]{3}{*}{ SL } & Min. & 172.0 & 44.3 & 48.1 & 45.5 & 65.2 & 48.1 & \\
\hline & Max. & 315.2 & 343.9 & 275.5 & 375.0 & 298.0 & 275.5 & \\
\hline & Mean & 261.3 & 200.5 & 212.0 & 193.1 & 192.6 & 212.0 & \\
\hline \multirow[t]{3}{*}{$\mathrm{BD}$} & Min. & 21.1 & 21.2 & 22.0 & 18.2 & 20.9 & 22.0 & $0.6372 / 0.4247$ \\
\hline & Max. & 28.8 & 29.7 & 25.7 & 21.8 & 23.6 & 25.7 & \\
\hline & Mean & 22.6 & 24.1 & 23.9 & 19.9 & 22.0 & 23.9 & \\
\hline \multirow[t]{3}{*}{$\mathrm{CPH}$} & Min. & 10.2 & 9.9 & 11.3 & 8.6 & 10.0 & 11.3 & $0.7692 / 0.3824$ \\
\hline & Max. & 12.5 & 12.6 & 12.3 & 11.3 & 12.1 & 12.3 & \\
\hline & Mean & 11.2 & 11.1 & 11.6 & 9.9 & 11.1 & 11.6 & \\
\hline \multirow[t]{3}{*}{$\mathrm{HD}$} & Min. & 19.9 & 27.1 & 28.7 & 21.3 & 20.9 & 28.7 & $0.9851 / 03232$ \\
\hline & Max. & 29.6 & 34.6 & 33.7 & 27.3 & 23.6 & 33.7 & \\
\hline & Mean & 29.8 & 30.6 & 32.0 & 24.5 & 22.0 & 32.0 & \\
\hline \multirow[t]{3}{*}{ ED } & Min. & 6.0 & 6.8 & 7.4 & 6.0 & 6.7 & 7.4 & $1.5514 / 0.2157$ \\
\hline & Max. & 6.8 & 11.3 & 11.0 & 10.5 & 11.2 & 11.0 & \\
\hline & Mean & 6.3 & 8.5 & 8.2 & 7.8 & 7.9 & 8.2 & \\
\hline \multirow[t]{3}{*}{ ID } & Min. & 8.8 & 7.7 & 7.9 & 6.2 & 6.9 & 7.9 & $0.1619 / 0.6874$ \\
\hline & Max. & 9.6 & 9.9 & 9.7 & 8.0 & 8.1 & 9.7 & \\
\hline & Mean & 9.2 & 8.8 & 8.9 & 7.0 & 7.5 & 8.9 & \\
\hline \multirow{7}{*}{$\begin{array}{l}\text { Meristic } \\
\text { Data }\end{array}$} & $1^{\text {st }} \mathrm{DS}$ & $14-16$ & $15-16$ & $15-16$ & $15-16$ & $14-16$ & $15-16$ & \\
\hline & $2^{\text {nd }}$ DS & $31-33$ & $31-33$ & $32-33$ & $31-33$ & $31-33$ & $32-33$ & \\
\hline & AFR & $11-12$ & $10-12$ & $11-12$ & $10-12$ & $11-12$ & $11-12$ & \\
\hline & PFRS & $13-14$ & $13-14$ & $13-14$ & $14-16$ & $14-15$ & $13-14$ & \\
\hline & ALL & $37-51$ & $35-51$ & $40-48$ & - & $42-56$ & $40-48$ & \\
\hline & PLL & $32-38$ & $31-39$ & $30-38$ & - & $32-41$ & $30-38$ & \\
\hline & MLL & $71-81$ & $70-79$ & $76-83$ & $88-109$ & 78-104 & $76-83$ & \\
\hline
\end{tabular}

Abbreviations as in Table 1.
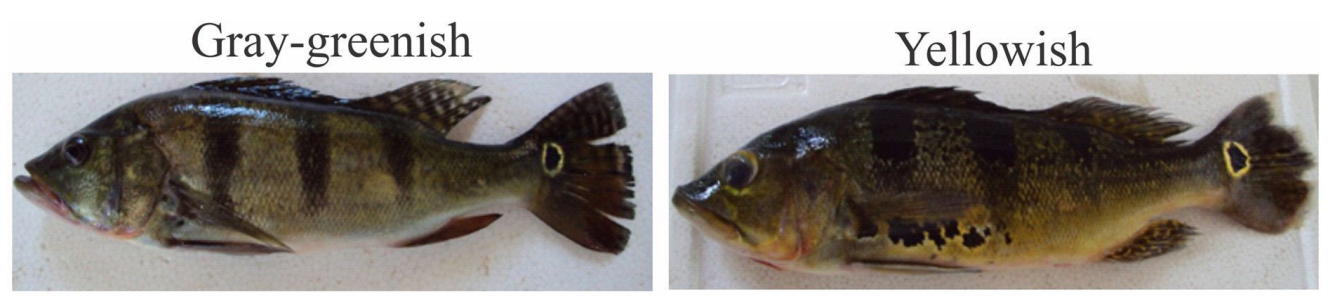

Figure 2. Gray-greenish and yellowish types of Cichla collected in the reservoirs of the submiddle stretch of São Francisco River.

The topologies determined by ML and BI were identical for the three markers. For COI, there was a clade formed by individuals of Cichla sampled from the São Francisco River and C. kelberi from the Tocantins River basin, and were separated from the other species with high Bayesian posterior probability $(\mathrm{BPP}=100 \%)$ and bootstrap $(94 \%)$ support values (Figure 3). For 16S, the topology also shows that specimens of $C$. kelberi from the Tocantins River form 


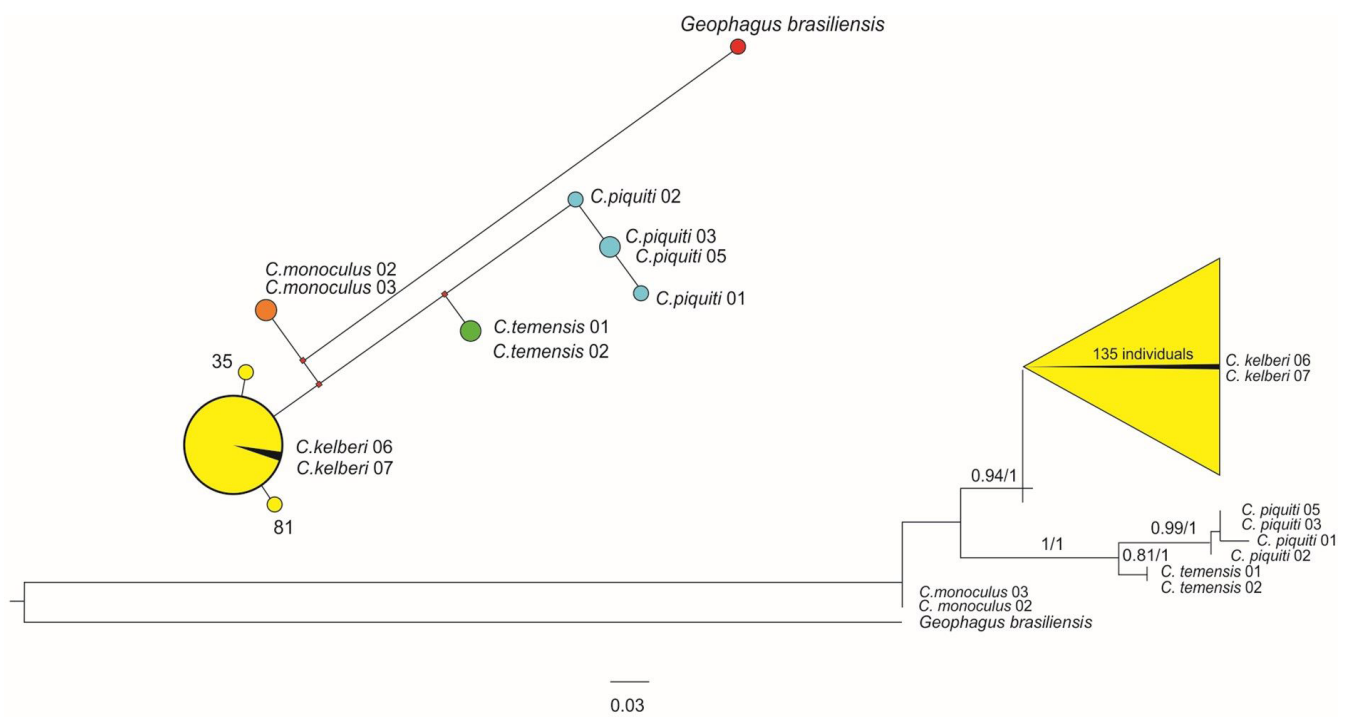

Figure 3. Bayesian consensus tree reconstructed based on sequences of Cichla individuals from the submiddle stretch of São Francisco River and reference sequences for COI. Haplotype network using median-joining method. Circles represent haplotypes and diameter represents frequency of haplotype.

a highly supported clade, with São Francisco River samples (BPP $=70 \%$ / bootstrap=95\%) separated from the other Cichla species (Supplementary material, Figure S1). Likewise, for $\mathrm{CR}$, the topology consisted of a main clade made of São Francisco River samples and C. kelberi from Tocantins River $(\mathrm{BPP}=99 \%$ and bootstrap $=100 \%)($ Supplementary material, Figure S2).

\section{Discussion}

The sampled peacock bass and the four Cichla species previously reported for the São Francisco River (Pompeu and Godinho, 2003; Sato and Sampaio, 2005; Carvalho et al., 2009), exhibited considerable overlapping morphometric variation and pigmentation patterns, limiting their clear identification. However, all the 135 individuals were grouped in a well-supported clade with C. kelberi for the three mtDNA markers.

The dramatic lack of diversity in terms of number of haplotypes observed among the 135 individuals of C. kelberi for the three markers offers evidential support of a founder effect derived from a single maternal lineage. The founder effect hypothesis is reinforced by the fact that in regions of natural occurrence of $C$. kelberi, five haplotypes of CR were observed in a sample of five individuals collected in São Felix do Araguaia, while three haplotypes were detected in three individuals taken in Tucuruí Reservoir, both belonging to the Tocantins basin (Marques et al., 2016). This level of intraspecific variation of CR in the natural habitat contrasts with the single haplotype recovered in the reservoirs of the São Francisco River derived from a single invasive maternal ancestor. Our results endorse the difficulty in accrediting genetic diversity for this invasion success. Hence, in this case the colonization success may rely on other factors, such as environmental ones.
The colonization of $C$. kelberi in the reservoir cascade of the submiddle stretch of the São Francisco River may have benefited from the reduction in water turbidity (Santos et al., 2018), favouring visual predators such as the peacock bass. Espínola et al. (2010), Franco et al. (2018) and Franco et al. (2021) have highlighted that abiotic variables, such as warmer temperature, lower turbidity and higher transparency benefit the invasibility of reservoirs by Cichla. Moreover, the construction of the studied reservoirs (Moxotó, Delmiro Gouveia and PA IV) within a stretch of the São Francisco River, isolated by river damming, led to the local extinction of some endemic rheophilic top predators, such as the dourado Salminus franciscanus (Lima \& Britski, 2007) and the surubim Pseudoplatystoma corruscans (Spix \& Agassiz, 1829) (Sato and Godinho, 2003), that could have potentially preyed on juvenile forms of Cichla.

Control strategies could be implemented to reduce the C. kelberi population in the São Francisco River, such as encouragement of underwater sport fishing targeting this species, with the creation, for example, of an ecotourism plan. Moreover, the catching of this species could be opened during the closed reproduction season, when the peacock bass becomes a voracious predator of juveniles of the native threatened migratory fish species. The restocking of native top predators from the São Francisco River Basin in these reservoirs could be implemented to reduce $C$. kelberi populations. However, these activities require public policies and academic studies to support management plans that could control their population size.

The three molecular markers (COI, 16S rRNA and CR) used in this study were essential in the identification and elucidation of the two color types found in reservoirs of the São Francisco River, which were actually a single species, the C. kelberi (C. ocellaris sensu lato). This study highlighted the fact that studies focusing on species of Cichla should rely on a detailed molecular analysis, as past studies were 
apparently unable to correctly identify specimens at the species level. Other invasions of $C$. kelberi, were confirmed by molecular markers, in a lake and in reservoirs of other hydrographic basins (Marques et al., 2016; Santos et al., 2016; Diamante et al., 2017). Future study should answer the question whether this species is dominant over other congeners' species in their establishment success or if it is inherent to that genus.

\section{Acknowledgements}

Funding for this project was provided through the Research and Technological Development Program of the Brazilian Electricity Regulatory Agency (ANEEL 0048-044/201). CAPES (Coordenação de Aperfeiçoamento de Pessoal de Nível Superior) is acknowledged for awarding a doctoral scholarship to the first author. We thank CNPq (Conselho Nacional de Desenvolvimento Científico e Tecnológico) for providing a research fellowship to Maria Raquel Moura Coimbra (grant 304518/2016-6). The authors are also indebted to Dr. Alberto Akama from the Museu Paraense Emílio Goeldi (Research Institute and Museum) - Belém (Brazil) for kindly providing muscle tissues from C. piquiti and to Dr. Mark Sabaj for providing samples of $C$. temensis (SUDAM - Proc. $n^{\circ}$ CUP 59004/00473/2013-42) and C. monoculus (Xingu Project).

\section{References}

BANDELT, H.J., FORSTER, P. and RÖHL, A., 1999. Median-joining networks for inferring intraspecific phylogenies. Molecular Biology and Evolution, vol. 16, no. 1, pp. 37-48. http://dx.doi. org/10.1093/oxfordjournals.molbev.a026036. PMid:10331250.

CARVALHO, D.C., OLIVEIRA, D.A.A., SANTOS, J.E., TESKE, P., BEHEREGARAY, L.B., SCHNEIDER, H. and SAMPAIO, I., 2009. Genetic characterization of native and introduced populations of the neotropical cichlid genus Cichla in Brazil. Genetics and Molecular Biology, vol. 32, no. 3, pp. 601-607. http://dx.doi. org/10.1590/S1415-47572009005000060. PMid:21637525.

CHENG, Y.-Z., XU, T.-J., JIN, X.-X., TANG, D., WEI, T., SUN, Y.-Y., MENG, F.-Q., SHI, G. and WANG, R.-X., 2012. Universal primers for amplification of the complete mitochondrial control region in marine fish species. Molecular Biology, vol. 46, no. 5, pp. 727-730. http://dx.doi.org/10.1134/S0026893312040024. PMid:23156681.

CRONIN, M.A., SPEARMAN, W.J., WILMOT, R.L., PATTON, J.C. and BICKHAM, J.W., 1993. Mitochondrial DNA variation in chinook (Oncorhynchus tshawytscha) and chum salmon (O. keta) detected by restriction enzyme analysis of polymerase chain reaction (PCR) products. Canadian Journal of Fisheries and Aquatic Sciences, vol. 50, no. 4, pp. 708-715. http://dx.doi.org/10.1139/f93-081.

DIAMANTE, N.A., DE OLIVEIRA, A.V., PETRY, A.C., CATELANI, P.A., PELICICE, F.M., PRIOLI, S.M.A.P. and PRIOLI, A.J., 2017. Molecular analysis of invasive Cichla (Perciformes: Cichlidae) populations from neotropical ecosystems. Biochemical Systematics and Ecology, vol. 72, pp. 15-22. http://dx.doi.org/10.1016/j. bse.2017.03.004.

ESPÍNOLA, L.A., MINTE-VERA, C.V. and JÚLIO JUNIOR, H.F., 2010. Invasibility of reservoirs in the Paraná Basin, Brazil, to Cichla kelberi Kullander and Ferreira, 2006. Biological Invasions, vol. 12, no. 6, pp. 1873-1888. http://dx.doi.org/10.1007/s10530009-9598-X.
FERRAREZE, M. and NOGUEIRA, M.G., 2015. Impact assessment of the introduction of Cichla kelberi in a large Neotropical reservoir and its lateral lagoons (Upper Paraná River Basin, Brazil). Brazilian Journal of Biology = Revista Brasileira de Biologia, vol. 75, no. 4, pp. 1018-1026. http://dx.doi.org/10.1590/15196984.05814. PMid:26675920.

FRAGOSO-MOURA, E.N., OPORTO, L.T., MAIA-BARBOSA, P.M. and BARBOSA, F.A.R., 2016. Loss of biodiversity in a conservation unit of the Brazilian Atlantic Forest: the effect of introducing non-native fish species. Brazilian Journal of Biology = Revista Brasileira de Biologia, vol. 76, no. 1, pp. 18-27. http://dx.doi. org/10.1590/1519-6984.07914. PMid:26909619.

FRANCO, A.C.S., GARCÍA-BERTHOU, E. and SANTOS, L.N., 2021. Ecological impacts of an invasive top predator fish across South America. The Science of the Total Environment, vol. 761, pp. 143296. http://dx.doi.org/10.1016/j.scitotenv.2020.143296. PMid:33187704.

FRANCO, A.C.S., SANTOS, L.N., PETRY, A.C. and GARCÍA-BERTHOU, E., 2018. Abundance of invasive peacock bass increases with water residence time of reservoirs in southeastern Brazil. Hydrobiologia, vol. 817, no. 1, pp. 155-166. http://dx.doi. org/10.1007/s10750-017-3467-x.

GOLANI, D., SONIN, O., SNOVSKY, G., DAVID, L. and TADMOR-LEVI, R., 2019. The occurrence of the peacock bass (Cichla kelberi Kullander and Ferreira 2006) in Lake Kinneret (Sea of Galilee), Israel. BioInvasions Records, vol. 8, no. 3, pp. 706-711. http:// dx.doi.org/10.3391/bir.2019.8.3.28.

GOMIERO, L.M. and BRAGA, F.M.S., 2003. Experimental fishing of "tucunaré", Cichla (Osteichthyes, Cichlidae), in Volta Grande Reservoir, Grande River ( $\left.48^{\circ} 25^{\prime}-47^{\circ} 35^{\prime} \mathrm{W}, 19^{\circ} 57^{\prime}-20^{\circ} 10^{\prime} \mathrm{S}\right)$. Boletim do Instituto de Pesca, vol. 29, no. 1, pp. 29-37.

GOMIERO, L.M., VILLARES JUNIOR, G.A. and NAOUS, F., 2009. Reproduction of Cichla kelberi Kullander and Ferreira, 2006 introduced into an artificial lake in southeastern Brazil. Brazilian Journal of Biology = Revista Brasileira de Biologia, vol. 69, no. 1, pp. 175-183. http://dx.doi.org/10.1590/S1519-69842009000100023. PMid: 19347162.

GUINDON, S. and GASCUEL, O., 2003. A simple, fast, and accurate algorithm to estimate large phylogenies by maximum likelihood. Systematic Biology, vol. 52, no. 5, pp. 696-704. http://dx.doi. org/10.1080/10635150390235520. PMid:14530136.

HASHIMOTO, D.T., PRADO, F.D., PORTO-FORESTI, F. and FORESTI, F., 2016. Molecular identification of intergenus crosses involving catfish hybrids: risks for aquaculture production. Neotropical Ichthyology, vol. 14, no. 2, pp. e150139. http:// dx.doi.org/10.1590/1982-0224-20150139.

HUELSENBECK, J.P. and RONQUIST, F., 2001. MRBAYES: bayesian inference of phylogenetic trees. Bioinformatics, vol. 17, no. 8, pp. 754-755. http://dx.doi.org/10.1093/bioinformatics/17.8.754. PMid:11524383.

KIMURA, M., 1980. A simple method for estimating evolutionary rates of base substitutions through comparative studies of nucleotide sequences. Journal of Molecular Evolution, vol. 16, no. 2, pp. 111-120. http://dx.doi.org/10.1007/BF01731581. PMid:7463489.

KULLANDER, S.O. and FERREIRA, E.J.G., 2006. A review of the South American cichlid genus Cichla with descriptions of nine new species (Teleostei: cichlidae). Ichthyological Exploration of Freshwaters, vol. 17, no. 4, pp. 289-398.

KUMAR, S., STECHER, G.G. and TAMURA, K., 2016. MEGA7: molecular evolutionary genetics analysis version 7.0 for bigger datasets. Molecular Biology and Evolution, vol. 33, no. 7, pp. 1870-1874. http://dx.doi.org/10.1093/molbev/msw054. PMid:27004904. 
LIBRADO, P. and ROZAS, J., 2009. DnaSP v5: A software for comprehensive analysis of DNA polymorphism data. Bioinformatics, vol. 25, no. 11, pp. 1451-1452. http://dx.doi. org/10.1093/bioinformatics/btp187. PMid:19346325.

LÓPEZ-FERNÁNDEZ, H., WINEMILLER, K.O. and HONEYCUTT, R.L., 2010. Multilocus phylogeny and rapid radiations in neotropical cichlid fishes Perciformes: Cichlidae: Cichlinae. Molecular Phylogenetics and Evolution, vol. 55, no. 3, pp. 1070-1086. http://dx.doi.org/10.1016/j.ympev.2010.02.020. PMid:20178851.

MARQUES, A.C.P.B., FRANCO, A.C.S., SALGUEIRO, F., GARCÍABERTHOU, E. and SANTOS, L.N., 2016. Genetic divergence among invasive and native populations of the yellow peacock cichlid Cichla kelberi. Journal of Fish Biology, vol. 89, no. 6, pp. 2595-2606. http://dx.doi.org/10.1111/jfb.13144. PMid:27679988.

MEYER, A., KOCHER, T.D., BASASIBWAKI, P. and WILSON, A.C., 1990. Monophyletic origin of Lake Victoria cichlid fishes suggested by mitochondrial DNA sequences. Nature, vol. 347, no. 6293, pp. 550-553. http://dx.doi.org/10.1038/347550a0. PMid:2215680.

MOYLE, P.B. and MARCHETTI, M.P., 2006. Predicting invasion success: freshwater fishes in California as a model. Bioscience, vol. 56, no. 6, pp. 515-524. http://dx.doi.org/10.1641/00063568(2006)56[515:PISFFI]2.0.CO;2.

PALUMBI, S.R., MARTIN, A.P., ROMANO, S., MCMILLAN, W., STICE, L. and GRABOWSKI, G., 1991. The simple fool's guide to PCR. Honolulu: University of Hawaii Press, 45 p.

PELICICE, F.M. and AGOSTINHO, A.A., 2009. Fish fauna destruction after the introduction of a non-native predator Cichla kelberi in a Neotropical reservoir. Biological Invasions, vol. 11, no. 8 , pp. 1789-1801. http://dx.doi.org/10.1007/s10530-008-9358-3.

PEREIRA, L.H., HANNER, R., FORESTI, F. and OLIVEIRA, C., 2013. Can DNA barcoding accurately discriminate megadiverse Neotropical freshwater fish fauna? BMC Genetics, vol. 14, no. 1, pp. 20. http://dx.doi.org/10.1186/1471-2156-14-20. PMid:23497346.

POMPEU, P.S. and GODINHO, H.P. 2003. Ictiofauna de três lagoas marginais do médio São Francisco. In: H.P. GODINHO and A.L. GODINHO, eds. Águas, peixes e pescadores do São Francisco das Minas Gerais. Belo Horizonte: PUC Minas, pp. 167-181.

POSADA, D., 2008. jModelTest: phylogenetic model averaging. Molecular Biology and Evolution, vol. 25, no. 7, pp. 1253-1256. http://dx.doi.org/10.1093/molbev/msn083. PMid:18397919.

QUADROS, J., FERREIRA, A.M., VIANA, P.F., MARAJÓ, L., OLIVEIRA, E., FERREIRA, E. and FELDBERG, E., 2020. Comparative cytogenetic of six species of Amazonian Peacock bass (Cichla, Cichlinae): intrachromosomal variations and genetic introgression among sympatric species. Comparative Cytogenetics, vol. 14, no. 3, pp. 437-451. http://dx.doi.org/10.3897/CompCytogen.v14i3.55279. PMid:33014295.

QURAISHIA, S.F., PANNEERCHELVAM, S., ZAINUDDIN, Z. and ABD RASHID, N.H., 2015. Molecular characterization of Malaysian marine fish species using partial sequence of mitochondrial DNA $12 \mathrm{~S}$ and $16 \mathrm{~S}$ rRNA markers. Sains Malaysiana, vol. 44, no. 8, pp. 1119-1123. http://dx.doi.org/10.17576/jsm-2015-4408-06.

REISS, P., ABLE, K.W., NUNES, M.S. and HRBEK, T., 2012. Color pattern variation in Cichla temensis (Perciformes: Cichlidae): resolution based on morphological, molecular, and reproductive data. Neotropical Ichthyology, vol. 10, no. 1, pp. 59-70. http://dx.doi. org/10.1590/S1679-62252012000100006.

ROHLF, F.J., 1990. Morphometrics. Annual Review of Ecology and Systematics, vol. 21, no. 1, pp. 299-316. http://dx.doi.org/10.1146/ annurev.es.21.110190.001503.
RONQUIST, F. and HUELSENBECK, J.P., 2003. Mrbayes 3: bayesian phylogenetic inference under mixed models. Bioinformatics, vol. 19, no. 12, pp. 1572-1574. http://dx.doi.org/10.1093/ bioinformatics/btg180. PMid:12912839.

SAAD, Y.M., 2019. Analysis of $16 S$ mitochondrial ribosomal DNA sequence variations and phylogenetic relations among some Serranidae fishes. South African Journal of Animal Science, vol. 49, no. 1, pp. 80-89. http://dx.doi.org/10.4314/sajas.v49i1.10.

SAMBROOK, J., FRITSCH, E.F. and MANIATIS, T., 1989. Molecular cloning: a laboratory manual. 2nd ed. New York: Cold Spring Harbor Laboratory Press.

SANTOS, L., FRANCO, A., MARQUES, A., NÓBREGA, F. and SALGUEIRO, F., 2016. Molecular analysis confirms the introduction of a second species of yellow peacock cichlid Cichla monoculus Spix \& Agassiz 1831 (Cichliformes: Cichlidae) in the Southeast Atlantic Hydrographic province, Brazil. BioInvasions Records, vol. 5, no. 4, pp. 277-284. http://dx.doi.org/10.3391/bir.2016.5.4.13.

SANTOS, N.C.L., GARCÍA-BERTHOU, E., DIAS, J.D., LOPES, T.M., AFFONSO, I.P., SEVERI, W., GOMES, L.C. and AGOSTINHO, A.A., 2018. Cumulative ecological effects of a Neotropical reservoir cascade across multiple assemblages. Hydrobiologia, vol. 819, no. 4, pp. 77-91. http://dx.doi.org/10.1007/s10750-018-3630-z.

SASTRAPRAWIRA, S.M., RAZAK, I.H.A., SHAHIMI, S., PATI, S., EDINUR, H.A., JOHN, A.B., AMIRRUDIN, A., JAYARAJ, V.K., MELISSA, B.M. and JU, L.C., 2020. A review on introduced Cichla spp. and emerging concerns. Heliyon, vol. 6, no. 11, pp. e05370. http:// dx.doi.org/10.1016/j.heliyon.2020.e05370. PMid:33204875.

SATO, Y. and GODINHO, H.P., 2003. Migratory fishes of the São Francisco River. In: J. CAROLSFELD, B. HARVEY, C. ROSS and A. BAER, ed. Migratory fishes of South America. Victoria: World Fisheries Trust, pp. 195-232.

SATO, Y. and SAMPAIO, E.V., 2005. A ictiofauna na região do alto São Francisco, com ênfase no reservatório de Três Marias, Minas Gerais. In: M.G. NOGUEIRA, R. HENRY and A. JORCIN, eds. Ecologia de reservatórios: impactos potenciais, ações de manejo e sistemas de cascata. São Carlos: Rima, pp. 251-274.

SHARPE, D.M., DE LEÓN, L.F., GONZÁLEZ, R. and TORCHIN, M.E., 2017. Tropical fish community does not recover 45 years after predator introduction. Ecology, vol. 98, no. 2, pp. 412-424. http:// dx.doi.org/10.1002/ecy.1648. PMid:27861787.

THOMPSON, J.D., HIGGINS, D.G. and GIBSON, T.J., 1994. ClustalW: improving the sensitivity of progressive multiple sequence alignment through sequence weighting, position specific gap penalties and weight matrix choice. Nucleic Acids Research, vol. 22, no. 22, pp. 4673-4680. http://dx.doi.org/10.1093/ nar/22.22.4673. PMid:7984417.

WARD, R.D., ZEMLAK, T.S., INNES, B.H., LAST, P.R. and HEBERT, P.D.N., 2005. DNA barcoding Australia's fish species. Philosophical Transactions of the Royal Society of London. Series B, Biological Sciences, vol. 360, no. 1462, pp. 1847-1857. http://dx.doi. org/10.1098/rstb.2005.1716. PMid:16214743.

WILLIS, S.C., MACRANDER, J., FARIAS, I.P. and ORTÍ, G., 2012. Simultaneous delimitation of species and quantification of interspecific hybridization in Amazonian peacock cichlids (genus Cichla) using multi-locus data. BMCEvolutionary Biology, vol. 12, no. 1, pp. 96. http://dx.doi.org/10.1186/1471-2148-12-96. PMid:22727018.

ZARET, T.M. and PAINE, R.T., 1973. Species introduction in a tropical lake: a newly introduced piscivore can produce population changes in a wide range of trophic levels. Science, vol. 182, no. 4111, pp. 449-455. http://dx.doi.org/10.1126/ science.182.4111.449. PMid:17832455. 


\section{Supplementary material}

Supplementary material accompanies this paper.

Figure S1. Bayesian consensus tree reconstructed based on sequences of Cichla individuals from the submiddle stretch of the São Francisco River and reference sequences for 16S rDNA. GenBank reference sequences were named as C. monoculus, C. temensis, C. kelberi and C. piquiti, followed by the last three digits of accession number.

Figure S2. Bayesian consensus tree reconstructed based on sequences of Cichla individuals from the submiddle stretch of the São Francisco River and reference sequences for Control Region. GenBank reference sequences were named as C. monoculus, C. temensis, C. kelberi and C. piquiti, followed by the last three digits of accession number.

This material is available as part of the online article from https://www.scielo.br/j/bjb 